\title{
Bacteroides multiacidus, a New Species from the Feces of Humans and Pigs
}

\author{
TOMOTARI MITSUOKA, ATSUSHI TERADA, KEIKO WATANABE, and KAZUO UCHIDA \\ Institute of Physical and Chemical Research, Wako, Saitama, 351, Japan, and Nippon Veterinary and \\ Zootechnical College, Musashino, Tokyo, 180, Japan
}

\begin{abstract}
Ninety-five strains of Bacteroides hypermegas Harrison and Hansen and of related organisms were isolated from the feces of humans, pigs, dogs, and chickens and were compared with three authentic strains of $B$. hypermegas. All isolates shared certain features in common: they were gram-negative, nonsporeforming, nonmotile, strictly anaerobic, stout rods which fermented a wide range of carbohydrates, had low final $\mathrm{pH}$ values in glucose broth (4.1 to 4.8), and were markedly stimulated by the presence of glucose in the medium. On the basis of a number of additional features, two distinct groups could be differentiated: 52 strains isolated from humans, chickens, and dogs were identical with $B$. hypermegas; the remaining 43 strains isolated from humans and pigs were considered to form a new species, for which the name Bacteroides multiacidus was proposed. B. multiacidus differs from B. hypermegas in that the former has the following: smaller size of cell $(0.8$ to $1.5 \mu \mathrm{m}$ by 3.0 to $20.0 \mu \mathrm{m})$; positive nitratase activity; low final $\mathrm{pH}$ value $(4.1$ to 4.3$)$ in glucose broth; ability to produce major amounts of lactic and acetic acids with moderate amounts of succinic acid but no propionic acid from glucose; ability to grow in the presence of sodium propionate $(15 \mathrm{mg} / \mathrm{ml})$ as well as to ferment melezitose, dextrin, and starch; and higher guanine plus cytosine content in the deoxyribonucleic acid ( 56 to $58 \mathrm{~mol} \%)$. The type strain of $B$. multiacidus is A $405-1$ (=ATCC $27723=$ NCTC 10934).
\end{abstract}

Harrison and Hansen $(8,9)$ isolated gramnegative, obligately anaerobic, nonsporeforming, large rods from the intestines of turkeys and proposed the name Bacteroides hypermegas for them. Barnes and Goldberg (1) isolated similar organisms from the cecum of chickens and later described them in detail as group 4 poultry strains $(2-4,7)$. The International Subcommittee on Gram-Negative Anaerobic Rods was of the opinion that all of these strains belong to the same species, B. hypermegas (5).

In the course of a study on the intestinal flora of humans and other animals, a large number of organisms was isolated which appeared to be identical with or closely related to $B$. hypermegas. However, some isolates differed sufficiently from the description of $B$. hypermegas to suggest that they might be classified as a new species. A study was undertaken, therefore, to determine the systematic position of these organisms.

\section{MATERIALS AND METHODS}

Bacterial strains. Ninety-eight strains were studied. The strains and their sources are listed in Table 1.
Twenty-five of these were isolated from human feces, 27 from chicken ceca, 32 from pig feces, 11 from dog feces, and 3 strains (EBF 58/74, EBF 61/42, EBF 61/61) were obtained from Ella M. Barnes, Food Research Institute, Norwich, England, as representative strains of her group 4 bacteria ( $B$. hypermegas).

Isolation and maintenance of cultures. Fecal materials emulsified in an anaerobic buffer solution were plated out on modified Eggerth-Gagnon (EG) agar, glucose blood liver (BL) agar, and neomycin brilliant green taurocholate blood agar as described by Mitsuoka, Sega, and Yamamoto $(13,14)$. Incubation was carried out at $37 \mathrm{C}$ in anaerobic steel wool jars (15) filled with an atmosphere of $100 \% \mathrm{CO}_{2}$. Plates were examined after 3 days, and representatives of the different colonial types were replated onto EG agar in order to check their purity. Strains were maintained on EG liver slants with $\mathrm{H}_{2} \mathrm{CO}_{3}-\mathrm{CO}_{2}$ buffer (14) and stored at $4 \mathrm{C}$. New transfers were made at 3-month intervals.

Morphological studies. EG agar and BL agar plates were streaked and incubated in an atmosphere of $100 \% \mathrm{CO}_{2}$ for 2 days. Cellular appearance was determined from Gram-stained smears. Colonies were examined for size, color, density, and elevation.

Physiological studies. For preparation of inocula and for most of the physiological studies, peptone yeast liver glucose starch (PYLGS) broth, with the following composition, was used: liver extract, 940 
TABLE 1. Designations and sources of the 98 strains used

\begin{tabular}{|c|c|c|c|}
\hline $\begin{array}{l}\text { Groups and } \\
\text { subgroups }\end{array}$ & Strain designations & Isolated from & Received from \\
\hline Ia & 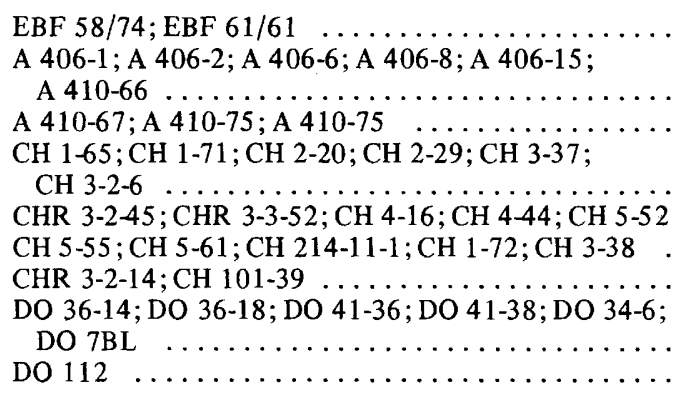 & $\begin{array}{l}\text { Cecum of chicken } \\
\text { Feces of man } \\
\text { Feces of man } \\
\text { Cecum of chicken } \\
\text { Cecum of chicken } \\
\text { Cecum of chicken } \\
\text { Cecum of chicken } \\
\text { Feces of dog } \\
\text { Feces of dog }\end{array}$ & $\begin{array}{l}\text { E. M. Barnes } \\
\text { Our collection } \\
\text { Our collection } \\
\text { Our collection } \\
\text { Our collection } \\
\text { Our collection } \\
\text { Our collection } \\
\text { Our collection } \\
\text { Our collection }\end{array}$ \\
\hline $\mathrm{Ib}$ & 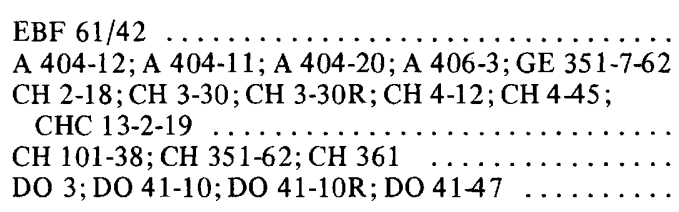 & $\begin{array}{l}\text { Cecum of chicken } \\
\text { Feces of man } \\
\text { Cecum of chicken } \\
\text { Cecum of chicken } \\
\text { Feces of dog }\end{array}$ & $\begin{array}{l}\text { E. M. Barnes } \\
\text { Our collection } \\
\text { Our collection } \\
\text { Our collection } \\
\text { Our collection }\end{array}$ \\
\hline IIa & A $405-1$; A 405-2; A 405-3; A 405-8; A 405-9 .... & Feces of man & Our collection \\
\hline IIb & $\begin{array}{l}\text { A } 402-44 ; \text { A } 402-45 ; \text { A } 402-56 ; \text { A } 402-59 ; \text { GE } 374-14 \\
\text { GE } 374-16 \ldots \ldots \ldots \\
\text { P } 10-8 ; \text { P } 206-5 ; \text { P } 206-15 ; \text { P } 207-29 ; \text { P } 207-31 ; \\
\text { P } 207-35 \ldots \ldots \\
\text { P } 207-42 ; \text { P } 208-44 ; \text { P } 208-51 ; \text { P } 208-58 ; \text { P } 209-72 \ldots \\
\text { P } 210-84 ; \text { P } 215-1 ; \text { P } 215-2 ; \text { P } 215-121 ; \text { P } 216-14 ; \\
\text { P } 216-15 \ldots \ldots \\
\text { P } 217-27 ; \text { P } 220-74 ; \text { P } 221-88 ; \text { P } 222-97 ; \text { P } 222-98 \ldots \\
\text { P 222-99;P } 223-109 ; \text { P } 223-110 ; \text { P } 223-111 ; \\
\text { P 224-120 } \ldots \ldots \\
\text { P } 224-121 ; \text { P } 227-1 ; \text { P } 227-2 ; \text { P } 230-44 ; \text { P } 230-45 \ldots\end{array}$ & $\begin{array}{l}\text { Feces of man } \\
\text { Feces of man } \\
\text { Feces of pig } \\
\text { Feces of pig } \\
\text { Feces of pig } \\
\text { Feces of pig } \\
\text { Feces of pig } \\
\text { Feces of pig }\end{array}$ & $\begin{array}{l}\text { Our collection } \\
\text { Our collection } \\
\text { Our collection } \\
\text { Our collection } \\
\text { Our collection } \\
\text { Our collection } \\
\text { Our collection } \\
\text { Our collection }\end{array}$ \\
\hline
\end{tabular}

$\mathrm{ml}$; beef extract (Lab-Lemco; Oxoid), $3 \mathrm{~g}$; yeast extract (Difco), $5 \mathrm{~g}$; proteose peptone no. 3 (Difco), $10 \mathrm{~g}$; $\mathrm{Na}_{2} \mathrm{HPO}_{4}, 4 \mathrm{~g}$; glucose, $1.5 \mathrm{~g}$; soluble starch, $0.5 \mathrm{~g}$; cysteine $\mathrm{HCl} \mathrm{H}_{2} \mathrm{O}, 0.2 \mathrm{~g}$; hemin solution, $20 \mathrm{ml} ; \mathrm{pH}$ 7.4 to 7.6 . The medium was autoclaved at $115 \mathrm{C}$ for $20 \mathrm{~min}$. The liver extract was prepared by adding $1,000 \mathrm{ml}$ of distilled water to $5.5 \mathrm{~g}$ of liver (Difco), holding at 50 to $60 \mathrm{C}$ for $1 \mathrm{~h}$, and then boiling for a few minutes. The extract was filtered. The hemin stock solution was prepared by adding $100 \mathrm{ml}$ of hemin stock solution $(50 \mathrm{mg}$ of hemin dissolved in 1 $\mathrm{ml}$ of $1 \mathrm{~N} \mathrm{NaOH}$; distilled water added to $100 \mathrm{ml}$ ) to 1 $\mathrm{ml}$ of sterile menadione solution $(100 \mathrm{mg}$ of menadione dissolved in $20 \mathrm{ml}$ of $95 \%$ ethyl alcohol and filter sterilized). The basal medium for certain physiological studies was PYLGS broth with glucose, soluble starch, and $\mathrm{Na}_{2} \mathrm{HPO}_{4}$ omitted. This medium was designated peptone yeast liver (PYL) broth.

For the determination of most of the physiological characters, $0.1 \mathrm{ml}$ of inoculum per $3 \mathrm{ml}$ of medium was used. All of the liquid media were held in a boiling-water bath for $20 \mathrm{~min}$ immediately before use, and then inoculated and incubated at $37 \mathrm{C}$ in anaerobic steel wool jars filled with an atmosphere of $90 \% \mathrm{~N}_{2}-10 \% \mathrm{CO}_{2}$ for 10 days, except where otherwise stated.
Acid production from carbohydrates was determined in PYL broth containing $0.25 \%(\mathrm{wt} / \mathrm{vol})$ of the carbohydrate to be tested and $2.8 \%$ (wt/vol) of bromocresol purple in $1.6 \%$ ethanolic solution. The following carbohydrates were employed: arabinose, xylose, ribose, rhamnose, sorbose, mannose, fructose, maltose, glucose, galactose, sucrose, cellobiose, lactose, trehalose, melibiose, raffinose, melezitose, dextrin, starch, glycogen, inulin, glycerol, mesoery thritol, adonitol, mannitol, sorbitol, dulcitol, aesculin, salicin, amygdalin, inositol, $\alpha$-methylglucoside, and $\alpha$-methylmannoside. The first eight were sterilized by filtration and added aseptically to the medium. Acid production was determined after 10 days of incubation.

The final $\mathrm{pH}$ values were measured electrometrically in PYL broth containing $1 \%$ glucose. The formation of gas in the fermentation of glucose $(1 \%)$ in PYL broth was detected by the appearance of bubbles in Durham tubes.

For the determination of fermentation products, PYL broth containing $1 \%$ glucose was used. The uninoculated medium served as control. The volatile fatty acids produced were determined by the method of Yoshioka, Kitamura, and Tamura (18), and nonvolatile fatty acids were determined by the method of Cato et al. (6). 
Nitrate reduction was determined in PYLGS broth containing $0.1 \% \quad \mathrm{KNO}_{3}$. Gelatin liquefaction was determined in PYL broth containing $15 \%$ gelatin and $0.2 \%$ glucose; cultures were examined at $4 \mathrm{C}$ after 10 days of incubation. A modified SIM medium (6) was used for the detection of motility and the production of $\mathrm{H}_{2} \mathrm{~S}$ and indole. Indole production was determined with Kovac reagent. Growth stimulation by bile or glucose was determined by adding $10 \%$ bile or $1 \%$ glucose to PYL broth with liver extract omitted. Results were determined by a visual comparison of the test tubes and controls.

The threonine test was performed by the method described by Suzuki, Ushijima, and Ichinose (16) with PYLGS broth. Glutamic acid decarboxylase activity was detected by the technique described by Suzuki et al. (16) using PYLGS broth containing 0.1\% L-glutamic acid.

Tolerance to inhibitory substances was determined in PYLGS broth containing the following substances: $0.001 \%$ brilliant green, $0.005 \%$ crystal violet, and $1.5 \%$ sodium propionate. RCM medium (Oxoid) was used for determining the sensitivity to neomycin $(25$ $\mu \mathrm{g} / \mathrm{ml})$, kanamycin $(100 \mu \mathrm{g} / \mathrm{ml})$, penicillin $(10 \mu \mathrm{g} / \mathrm{ml})$, polymyxin B $(10 \mu \mathrm{g} / \mathrm{ml})$, colistin $(10 \mu \mathrm{g} / \mathrm{ml})$, erythromycin $(50 \mu \mathrm{g} / \mathrm{ml})$, bacitracin $(3 \mathrm{U} / \mathrm{ml})$, and rifampin $(10 \mu \mathrm{g} / \mathrm{ml})$.

DNA base composition. The mol per cent of guanine plus cytosine $(G+C)$ in the deoxyribonucleic acid (DNA) was determined by thermal denaturation as described by Marmur and Doty $(11,12)$.

\section{RESULTS}

Characters common to all strains. All of the strains studied shared certain features in common: they were gram-negative, nonsporeforming, nonmotile, large, stout rods $(0.8$ to $2.0 \mu \mathrm{m}$ by 3.0 to $20.0 \mu \mathrm{m}$ ) with rounded ends. They occurred singly, in short chains, or in irregular groups and were characterized by their regularity of shape (Fig. 1). Cells grown on BL agar were larger than those on EG agar.

Surface colonies on EG agar or BL agar plates were grayish-white, rough, circular, and convex with an irregular surface and edge and were 3 to $8 \mathrm{~mm}$ in diameter (Fig. 1). Dark brown to black colonies, such as those produced by $B$. melaninogenicus, were never seen. Slight hemolysis was produced on EG agar plates by a few strains.

Growth occurred only under strictly anaerobic conditions and was markedly enhanced by the presence of glucose (or other fermentable carbohydrate) in the medium, but not by bile.

The physiological features of the strains are shown in Table 2. Like Bacteroides strains, they differed from Sphaerophorus and Fusobacterium strains in their inability to produce butyric acid from glucose, but they differed

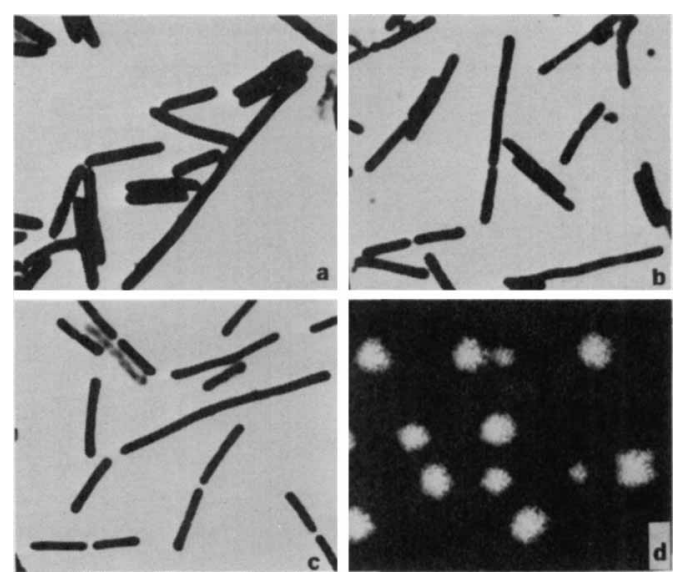

FIG. 1. Cell and colony of group I (B. hypermegas) and group II (B. multiacidus) on BL agar, $48 \mathrm{~h}$ at $37 \mathrm{C}$ incubation. (a) Cells of B. hypermegas EBF 58/74, Gram-stained smear; $\times 1,400$. (b) Cells of $B$. multiacidus A 405-1, Gram-stained smear; $\times 1,400$. (c) Cells of $B$. multiacidus $P$ 208-58, Gram-stained smear; $\times$ 1,400. (d) Colonies of B. multiacidus A 405-1; $\times 3$.

from many Bacteroides strains in their ability to grow in the presence of $0.001 \%$ brilliant green or $0.005 \%$ crystal violet and in their inability to grow in the presence of polymixin B $(10 \mu \mathrm{g} / \mathrm{ml})$ or colistin $(10 \mu \mathrm{g} / \mathrm{ml})$. All strains grew in the presence of rifampin $(10 \mu \mathrm{g} / \mathrm{ml})$.

Recently, L. R. Hill, National Collection of Type Cultures, Central Public Health Laboratory, London, England, determined the DNA base ratios of two strains of subgroup IIb, GE 374-14 and $P$ 208-58, and found that both had a $\mathrm{G}+\mathrm{C}$ ratio of approximately $56 \mathrm{~mol} \%$. This result was also comfirmed by us. The $\mathrm{G}+\mathrm{C}$ value for one strain (A 405-1) of subgroup IIa was $57.3 \mathrm{~mol} \%$.

\section{DISCUSSION}

On the basis of their physiological characteristics, the 98 strains studied can be divided into two distinct groups.

Group I consists of strains regarded as belonging to $B$. hypermegas and contains 55 strains, of which 14 were isolated from humans, 30 from chickens (including the 3 strains from E. M. Barnes), and 11 from dogs. They occurred in amounts of $10^{7}$ to $10^{9} / \mathrm{g}$ of cecal or fecal material from these animals.

The members of group I differed from those of group II by having the following: a larger cell size ( 1.0 to $2.0 \mu \mathrm{m}$ by 3.0 to $20.0 \mu \mathrm{m}$ ) (see Fig. 1); a higher final $\mathrm{pH}$ value (4.5 to 4.8$)$ in glucose broth; an ability to produce major amounts of acetic and propionic acids with 
INT. J. SYST. BACTERIOL.

TABLE 2. Characteristics of 55 strains of Bacteroides hypermegas and 43 strains of Bacteroides multiacidus

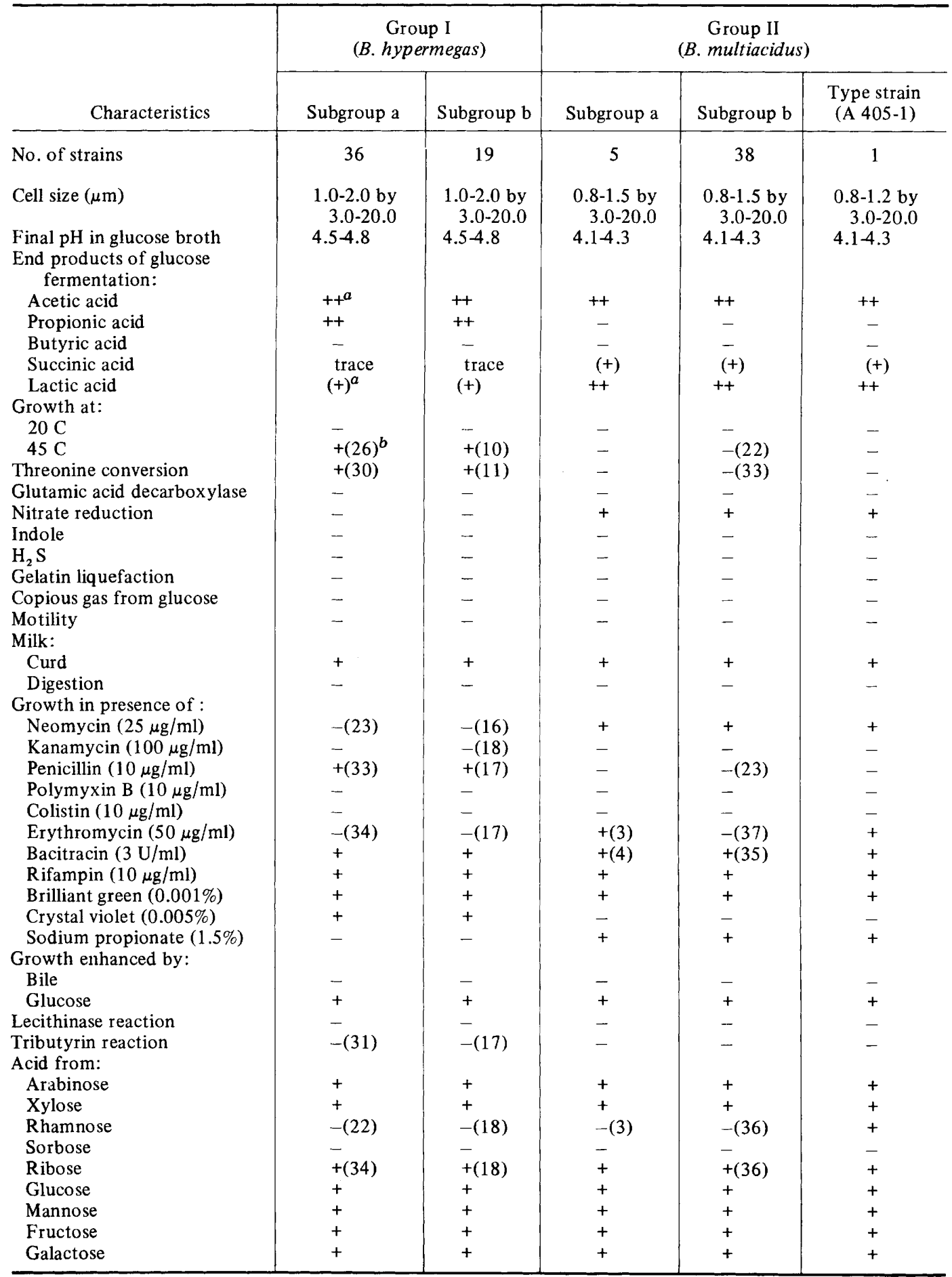


TABLE 2-Continued

\begin{tabular}{|c|c|c|c|c|c|}
\hline \multirow[b]{2}{*}{ Characteristics } & \multicolumn{2}{|c|}{$\begin{array}{c}\text { Group I } \\
\text { (B. hypermegas) }\end{array}$} & \multicolumn{3}{|c|}{$\begin{array}{l}\text { Group II } \\
\text { (B. } \text { multiacidus) }\end{array}$} \\
\hline & Subgroup a & Subgroup b & Subgroup a & Subgroup b & $\begin{array}{c}\text { Type strain } \\
\text { (A 405-1) }\end{array}$ \\
\hline Sucrose & + & + & + & + & + \\
\hline Maltose & + & + & + & + & + \\
\hline Cellobiose & $+(31)$ & $+(17)$ & + & + & + \\
\hline Lactose & + & + & + & + & + \\
\hline Trehalose & + & $+(17)$ & + & $+(32)$ & + \\
\hline Melibiose & + & + & + & + & + \\
\hline Raffinose & + & + & + & + & + \\
\hline Melezitose & - & - & + & + & + \\
\hline Dextrin & - & - & + & + & + \\
\hline Starch & - & - & + & + & + \\
\hline Gly cogen & - & - & $-(3)$ & $-(32)$ & - \\
\hline Inulin & - & - & - & - & - \\
\hline Glycerol & $-(33)$ & $-(17)$ & - & - & - \\
\hline Mesoerythritol & - & - & - & - & - \\
\hline Adonitol & - & - & - & - & - \\
\hline Mannitol & + & + & + & - & + \\
\hline Sorbitol & + & + & - & + & - \\
\hline Inositol & + & - & + & + & + \\
\hline Dulcitol & $-(32)$ & $-(17)$ & - & - & - \\
\hline Aesculin & $-(35)$ & $-(18)$ & + & + & + \\
\hline Salicin & $-(23)$ & $-(11)$ & + & + & + \\
\hline Amygdalin & - & - & - & - & -- \\
\hline$\alpha$-Methylglucoside & + & + & $-(4)$ & $-(34)$ & - \\
\hline$\alpha$-Methylmannoside & - & - & - & - & - \\
\hline Source of strains examined & & & & & \\
\hline Human & 9 & 5 & 5 & 6 & 1 \\
\hline Chicken & 20 & 10 & & & \\
\hline Pig & & & & 32 & \\
\hline Dog & 7 & 4 & & & \\
\hline
\end{tabular}

$a$ Symbols: ++ , major acid product; $(+)$, moderate product.

$b$ Numbers in parentheses refer to the number of strains which gave the reaction indicated. Where no numbers are given in parentheses, all of the strains gave the reaction indicated.

moderate amounts of lactic acid from glucose; an inability to ferment melezitose, dextrin, or starch; and an ability to grow in the presence of $0.005 \%$ crystal violet but not in $1.5 \%$ sodium propionate. All strains of group I produced acid from mannitol, sorbitol, and $\alpha$-methylglucoside and grew in the presence of bacitracin $(3 \mathrm{U} / \mathrm{ml})$. Many strains of this group grew in the presence of penicillin $(10 \mu \mathrm{g} / \mathrm{ml})$ but were inhibited by $25 \mu \mathrm{g}$ of neomycin per $\mathrm{ml}$ and $50 \mu \mathrm{g}$ of erythromycin per $\mathrm{ml}$, grew at $45 \mathrm{C}$, and produced propionic acid from threonine. This group was divided into two subgroups (Ia and Ib) by the fermentation of inositol. Members of both subgroups were isolated from the feces of humans, chickens, and dogs. Group I is identical with $B$. hypermegas as defined by Barnes and her associates $(1-4,7)$ on the basis of morphological, physiological, and biochemical characteristics.
Group II includes 43 strains, of which 11 were isolated from $m$ an and 32 from pigs. They were found to be present in amounts of $10^{6}$ to $10^{8} / \mathrm{g}$ of fecal material from these animals. Members of this group were distinguished from those of group I by the following characteristics: smaller cell size on $\mathrm{BL}$ agar, varying from 0.8 to $1.5 \mu \mathrm{m}$ by 3.0 to $20.0 \mu \mathrm{m}$ (see Fig. 1); consistently low final $\mathrm{pH}$ value $(4.1$ to 4.3$)$ in glucose broth; production of major amounts of lactic and acetic acids with moderate amounts of succinic acid in glucose broth; positive nitratase activity; inhibition by $0.005 \%$ crystal violet; growth in the presence of $1.5 \%$ sodium propionate; and ability to ferment melezitose, dextrin, and starch. The majority of strains of group II were inhibited by penicillin ( 10 $\mu \mathrm{g} / \mathrm{ml}$ ), were unable to grow at $45 \mathrm{C}$ or to produce propionic acid from threonine, and had no lipolytic activity. In addition, they grew 
in the presence of neomycin $(25 \mu \mathrm{g} / \mathrm{ml})$ and produced acid from cellobiose, inositol, aesculin, and salicin. Thus, these strains form a well-defined and easily recognizable group. Two subdivisions (subgroups IIa and IIb) were recognized within this group by the fermentation of mannitol and sorbitol. Members of subgroup IIa were isolated only from humans and those of subgroup IIb from humans and pigs.

The characters of the strains in group II are quite different from those of typical Bacteroides strains. However, it is felt that at present there is insufficient evidence on the organisms of the family Bacteroidaceae to permit the placement of the group II strains in a new genus. It seems appropriate, therefore, that these organisms be retained within the genus Bacteroides.

The G+C values (56 to $58 \%$ ) of the few group II strains on which these determinations were made differ markedly from the ratios of 32.1 and $34.8 \mathrm{~mol} \%$ for two strains of $B$. hypermegas (4), which compare favorably with the base ratios (27 to $34 \mathrm{~mol} \%$ ) for Sphaerophorus (17) and for Leptotrichia buccalis (34 mol \%) (10); they also differ from the values $(>41 \mathrm{~mol} \%)$ for Bacteroides species reported by Werner (17). Such differences provide sufficient evidence for separating group II strains from those of group I at least at the species level. The group II strains are considered to be a hitherto undescribed species, for which the name Bacteroides multiacidus is proposed. (L. adj. multus many, much; L. adj. acidus sour; M. L. neut. n. acidum acid; M. L. adj. multiacidus intended to mean "producing much acid.") The characteristics of B. multiacidus are as follows.

Morphology: gram-negative, nonsporeforming, nonmotile, large, stout rods ( 0.8 to $1.5 \mu \mathrm{m}$ in width and 3.0 to $20.0 \mu \mathrm{m}$ in length) of regular shape with rounded ends. Cells occur singly, in short chains, or in irregular groups.

Colonies on glucose blood agar after 2 days of incubation are grayish-white, roughly circular, convex, and 3 to $8 \mathrm{~mm}$ in diameter and have an irregular surface and edge; a slight hemolysis is produced by a few strains; dark brown pigment not produced.

Strictly anaerobic.

Final $\mathrm{pH}$ in glucose broth: 4.1 to 4.3 .

Acid from arabinose, xylose, glucose, fructose, galactose, sucrose, maltose, mannose, lactose, cellobiose, melibiose, raffinose, melezitose, dextrin, starch, inositol, aesculin, and salicin. Some cultures ferment mannitol and sorbitol. Ribose and trehalose usually fermented. Rhamnose, glycogen, and $\alpha$-methylglucoside usually not fermented. Glycerol, dulcitol, inulin, mesoerythritol, adonitol, amygdalin, $\alpha$-methylmannoside, and sorbose are not fermented.

No copious gas formation from glucose.

Major products from glucose fermentation are lactic and acetic acids, usually with moderate amounts of succinic acid.

No or poor growth in media without fermentable carbohydrate.

Bile is not stimulatory for growth.

Optimal temperature: about $37 \mathrm{C}$.

Gelatin not liquefied.

Indole not produced.

Hydrogen sulfide not produced.

Nitrate reduced to nitrite.

Acid and clot produced in milk.

Lecithinase not produced in egg yolk agar.

Tributyrin not hydrolyzed.

Threonine deaminase not produced.

Glutamic acid decarboxylase not produced.

Sensitive to kanamycin, polymyxin, and colistin. Resistant to rifampin. Variable sensitivity to penicillin, erythromycin, and bacitracin.

Tolerant to $1.5 \%$ sodium propionate and $0.001 \%$ brilliant green but not to $0.005 \%$ crystal violet.

Guanine plus cytosine content of DNA: 56 to $58 \mathrm{~mol} \%$.

Source: isolated from the feces of man and pigs.

Type strain: A 405-1 $(=$ ATCC $27723=$ NCTC 10934).

Reference strain for subgroup IIb: P 208-58 (= ATCC $27724=$ NCTC 10935).

Description of the type strain, A 405-1: The morphological and cultural characteristics of the type strain are the same as those given above for the species. Guanine plus cytosine content of DNA: $57.3 \mathrm{~mol} \%$. The other properties of this strain are given in Table 2 .

\section{ACKNOWLEDGMENTS}

We thank Ella M. Barnes, Food Research Institute, England, for supplying three authentic strains of $B$. hypermegas and for helpful suggestions and also L. R. Hill, National Collection of Type Cultures, London, England, for the determination of the base ratios of two strains of $B$. multiacidus.

\section{REPRINT REQUESTS}

Address reprint requests to: Dr. Tomotari Mitsuoka, Rikagaku Kenkyusho (The Institute of Physical and Chemical Research), Wako-shi, Saitama, 351, Japan.

\section{LITERATURE CITED}

1. Barnes, E. M., and H. S. Goldberg. 1962. The isolation of anaerobic gram-negative bacteria from 
poultry reared with and without antibiotic supplement. J. Appl. Bacteriol. 25:94-106.

2. Barnes, E. M., and H. S. Goldberg. 1965. The bacteroides of poultry caeca and their relationship with human strains. Ernährungsforschung 10:289-297.

3. Barnes, E. M., and H. S. Goldberg. 1968. The relationships of bacteria within the family Bacteroidaceae as shown by numerical taxonomy. $\mathrm{J}$. Gen. Microbiol. 51:313-324.

4. Barnes, E. M., and C. S. Impey. 1968. Anaerobic gram negative nonsporing bacteria from the caeca of poultry. J. Appl. Bacteriol. 31:530-541.

5. Beerens, H. 1970. Report of the international committee on nomenclature of bacteria, taxonomic subcommittee for gram-negative anaerobic rods. Int. J. Syst. Bacteriol. 20:297-300.

6. Cato, E. P., C. S. Cummins, L. V. Holdeman, J. L. Johnson, W. E. C. Moore, R. M. Smibert, and L. DS. Smith. 1970. Outline of clinical methods in anaerobic bacteriology, 2nd rev. Virginia Polytechnic Institute and State University, Blacksburg, Va.

7. Goldberg, H. S., E. M. Barnes, and A. B. Charles. 1964. Unusual Bacteroides-like organisms. J. Bacteriol. 87: 737-742.

8. Harrison, A. P., and P. A. Hansen. 1950. The bacterial flora of the cecal feces of healthy turkeys. J. Bacteriol. 59:197-210.

9. Harrison. A. P., and P. A. Hansen. 1963. Bacteroides hypermegas nov. spec. Antonie von Leeuwenhoek J. Microbiol. Serol. 29:22-28.
10. Hofstad, J. 1970. Leptotrichia buccalis, a gramnegative bacterium. Int. J. Syst. Bacteriol. 20:175-177.

11. Marmur, J. 1961. A procedure for the isolation of deoxyribonucleic acid from microorganisms. J. Mol. Biol. 3: 208-218.

12. Marmur, J., and P. Doty. 1962. Determination of the base composition of deoxyribonucleic acid from its thermal denaturation temperature. J. Mol. Biol. 5: 109-118.

13. Mitsuoka, T., T. Sega, and S. Yamamoto. 1964. Ein neuer Selektivnährboden für Bacteroides. Zentralbl. Bakteriol. Parasitenk. Infektionskr. Hyg. I. Orig. 195:69-79.

14. Mitsuoka, T., T. Sega, and S. Yamamoto. 1965. Eine verbesserte Methodik der qualitativen und quantitativen Analyse der Darmflora von Menschen und Tieren. Zentralbl. Bakteriol. Parasitenk. Infektionskr. Hyg. I. Orig. 195:455-469.

15. Parker, C. A. 1955. Anaerobiosis with iron wool. Aust. J. Exp. Biol. Med. Sci. 33:33-38.

16. Suzuki, S., T. Ushijima, and H. Ichinose. 1966. Differentiation of Bacteroides from Sphaerophorus and Fusobacterium. Jap. J. Microbiol. 10:193-200.

17. Werner, H. 1968. Die gramnegativen anaeroben sporenlosen Stäbchen des Menschen. Gustav Fischer Verlag, Jena.

18. Yoshioka, M., M. Kitamura, and Z. Tamura. 1969. Rapid gas chromatographic analysis of microbial volatile metabolites. Jap. J. Microbiol. 13: 87-93. 